\title{
Correction to: Validation of the Chinese version of the low physical activity questionnaire (LoPAQ) with ActiGraph accelerometer in hemodialysis patients
}

Rui Huang ${ }^{1,2}$, Haifen Zhang ${ }^{3}$, Yan Yang ${ }^{3}$, Nina Fang ${ }^{3}$, Qian Liư ${ }^{3}$, Jun Ma ${ }^{4}$, Min Wang ${ }^{3}$, Ling Shi ${ }^{3}$ and Xingjuan Tao ${ }^{\text {1* }}$

Correction to: BMC Nephrol 22, 17 (2021)

https://doi.org/10.1186/s12882-021-02230-3

Following publication of the original article [1], the authors informed us that the given name and family name of the authors were switched.

The author group has been updated above and the original article [1] has been corrected.

\begin{abstract}
Author details
'Shanghai Jiao Tong University School of Nursing, No.227, South Chongqing Rd, Shanghai 200025, China. ${ }^{2}$ Department of Biomedical Engineering, National University of Singapore, Singapore, Singapore. ${ }^{3}$ Nursing Department, Renji Hospital, School of Medicine, Shanghai Jiao Tong University, Shanghai, China. ${ }^{4}$ Department of Nephrology, Tong Ren Hospital, Shanghai Jiao Tong University School of Medicine, Shanghai, China.
\end{abstract}

Published online: 21 January 2021

\section{Reference}

1. Huang et al. Validation of the Chinese version of the low physical activity questionnaire (LoPAQ) with ActiGraph accelerometer in hemodialysis patients. BMC Nephrol. 2021;22:17. https://doi.org/10.1186/s12882-02102230-3.

The original article can be found online at https://doi.org/10.1186/s12882021-02230-3.

* Correspondence: tao.xingjuan@shsmu.edu.cn

'Shanghai Jiao Tong University School of Nursing, No.227, South Chongqing Rd, Shanghai 200025, China

Full list of author information is available at the end of the article

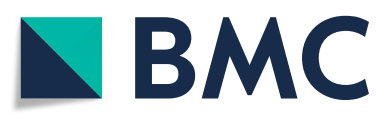

(- The Author(s). 2021 Open Access This article is licensed under a Creative Commons Attribution 4.0 International License, which permits use, sharing, adaptation, distribution and reproduction in any medium or format, as long as you give appropriate credit to the original author(s) and the source, provide a link to the Creative Commons licence, and indicate if changes were made. The images or other third party material in this article are included in the article's Creative Commons licence, unless indicated otherwise in a credit line to the material. If material is not included in the article's Creative Commons licence and your intended use is not permitted by statutory regulation or exceeds the permitted use, you will need to obtain permission directly from the copyright holder. To view a copy of this licence, visit http://creativecommons.org/licenses/by/4.0/. The Creative Commons Public Domain Dedication waiver (http://creativecommons.org/publicdomain/zero/1.0/) applies to the data made available in this article, unless otherwise stated in a credit line to the data. 